\title{
Cassava production as a climate change adaptation strategy in Chilonga Ward, Chiredzi District, Zimbabwe
}

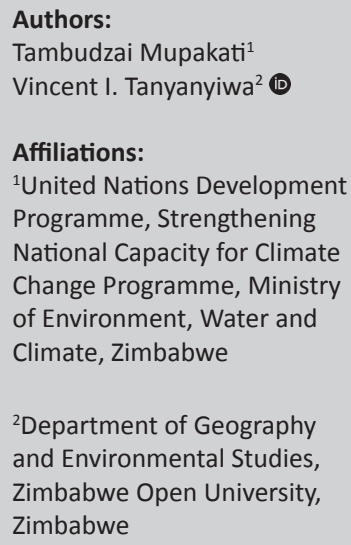

${ }^{2}$ Department of Geography and Environmental Studies, Zimbabwe Open University, Zimbabwe

\section{Corresponding author:} Vincent Tanyanyiwa, tanyanyiwavi@yahoo.com

Dates:

Received: 10 July 2016 Accepted: 31 Jan. 2017 Published: 25 Apr. 2017

How to cite this article: Mupakati, T. \& Tanyanyiwa, V.I., 2017, 'Cassava production as a climate change adaptation strategy in Chilonga Ward, Chiredzi District, Zimbabwe', Jàmbá: Journal of Disaster Risk Studies 9(1), a348. https:// doi.org/10.4102/jamba. v9i1.348

\section{Copyright:}

(c) 2017. The Authors. Licensee: AOSIS. This work is licensed under the Creative Commons Attribution License.
This study sought to pilot a range of long-term adaptation measures in the agriculture sector because of climate change shocks. Past droughts in Zimbabwe have had devastating environmental and socio-economic impacts in rural areas where livelihoods mainly depend on agriculture. Over the past few years, many parts of Zimbabwe have been experiencing extreme events. The study sought to address the following objectives to describe smallholder farmers' knowledge of climate change variability and change in Chilonga Ward and to explore the potential of cassava production as a climate change adaptation strategy in Chiredzi. An assessment of the impact of cassava production on rural livelihoods as a climate change adaptation strategy was also done. Focus group discussions, in-depth interviews, desk research and observation were the tools used to collect data. The results show that cassava has an extensive root system that can penetrate poor soils which may not support crops like maize. Zimbabwe has to increase cassava production as its tubers can be value added to produce a range of products that include livestock feed and porridge.

\section{Introduction}

One of the key challenges facing humanity today is climate change. The Fourth Assessment Report of the Intergovernmental Panel on Climate Change (IPCC 2007, 2010) indicates that the energy balance within the Earth's climate system has been altered, and this has resulted in significant changes in national, regional and world climate. IPCC (2007) has observed increases in average air and ocean temperatures, widespread melting of snow and ice, and rising global average sea level. In Zimbabwe, climate change presents risks to lives and livelihoods at the individual level and to the economy, and the livelihoods of the poor are highly vulnerable to climate change because of heavy reliance on rain-fed agriculture (Brown 2011). Zimbabwe has not been spared from the effects of climate change (Downing 1991). The country's annual mean surface temperature has warmed by about $0.4{ }^{\circ} \mathrm{C}$ from 1900 to 2000 (Chigwada 2009). The occurrence and amount of rainfall is becoming increasingly uncertain and the two decades from 1980 have witnessed a trend towards reduced rainfall or heavy rainfall and drought occurring in the same season (GoZ-UNDP/GEF 2009).

Chitiyo and Kasele (2004) assert that the most plausible strategy, therefore, is not only crop diversification but also cultivation of alternative low-input crops such as cassava (Manihot esculenta Crantz), which can tolerate the stressful conditions such as drought, acidity and low soil fertility (Asher, Edwards \& Howeler 1980; Challinor et al. 2007). Cassava is a potentially high yielding root crop of South American origin. It was introduced into Africa by Portuguese traders in the 16th century and into Zimbabwe from Angola, Malawi, Mozambique, Zaire and Zambia (Carter, Fresco \& Jones 1992). No specific production skills are required to grow cassava, which tolerates drought, acidity and low soil fertility (Asher et al. 1980; Hahn, Reynolds \& Egbunike 1988). It is against this background that this study sought to probe the potential of cassava production as climate change adaptation strategy in Chilonga in Chiredzi, Zimbabwe.

\section{Climate change and agriculture}

The IPCC (2007) defines climate change as a change in the state of the climate that can be identified (e.g. by using statistical tests) by changes in the mean and the variability of its properties, and that persists for an extended period, typically decades or longer. Adaptation means anticipating the adverse effects of climate change and taking appropriate action to prevent or minimise the damage they can cause or taking advantage of opportunities which may arise (IPCC 2007).

Note: This article's conceptual framework has been derived from and is partially based on the author's own previously published work, available here: http://www.iosrjournals.org/iosr-jhss/papers/Vol20-issue2/Version-4/J020245865.pdf 
Cassava (M. esculenta) is extensively cultivated as an annual crop in tropical and subtropical regions of Africa, Asia and Latin America between $30^{\circ} \mathrm{N}$ and $30^{\circ} \mathrm{S}$ (Duangpatra 1988; ElSharkawy 2006). The total global cassava production in 2009 was about 241 million tonnes, with Africa being the leading producer (FAOSTAT 2010). Cassava is considered a staple root crop for more than 800 million people living in developing tropical countries (Burns, Johnston \& Schmitz 2003). About $70 \%$ of world cassava root production is used for human consumption either directly after cooking or in processed forms. The remaining $30 \%$ is used for animal feed and other industrial products, such as starch, glucose and alcohol (El-Sharkawy 2004). In Brazil and China, cassava is being increasingly used for bioethanol production, while in Nigeria it is a major cash crop earning the country about three billion United States Dollars annually through export of the crop and related products (FAO 2007).

Although cassava requires optimal conditions to achieve high growth rates, it performs well in drought-prone areas and on poor soils and is thus considered one of the most productive tropical crops on marginal lands (Zhang et al. 2008). In seasonally dry and semi-arid environments with less than $700 \mathrm{~mm}$ of annual rain, improved cultivars of cassava can give dry root yields of over 3 tonnes/ha (ElSharkawy 2006). Therefore, cassava is often considered an insurance and hence major food security crop for resourcepoor smallholder farmers in marginal lands (Kamukondiwa 1996).

\section{Conceptual framework}

Farmers make decisions at the extensive margin (what to produce at site) and intensive margin (how to produce at a site) in order to maximise economic returns. New perspectives in research on climate change adaptation posit that sociocognitive factors may be important in motivating individuals to take adaptive actions (Frank et al. 2010). Mitchell (1982) defines motivation as the degree to which an individual wants and chooses to engage in certain specified behaviour. Motivation theory explains the cognitive and psychological processes that drive actions in order to predict behaviour (Mitchell 1982). Maslow's hierarchy of needs posits that the underlying needs for all human motivation are on five general levels from the lowest to the highest: physiological needs, safety needs, belongingness needs, esteem needs and self-actualisation.

Motivation cannot be observed or measured directly, but can manifest itself through attitudinal and behavioural measures (Ambrose \& Kulik 1999). Behavioural manifestations may include active pursuit and use of information and implementation of adaptations. However, identifying both the generic- and climate-specific elements of smallholder farmers' adaptation behaviour is vital in order to facilitate a societal response to the changes that climate scientists have predicted (Sieber et al. 2010). Tailoring adaptation practices to specific societies may make it possible to offset the adverse impacts of climate change (Fussel 2007). Moreover,

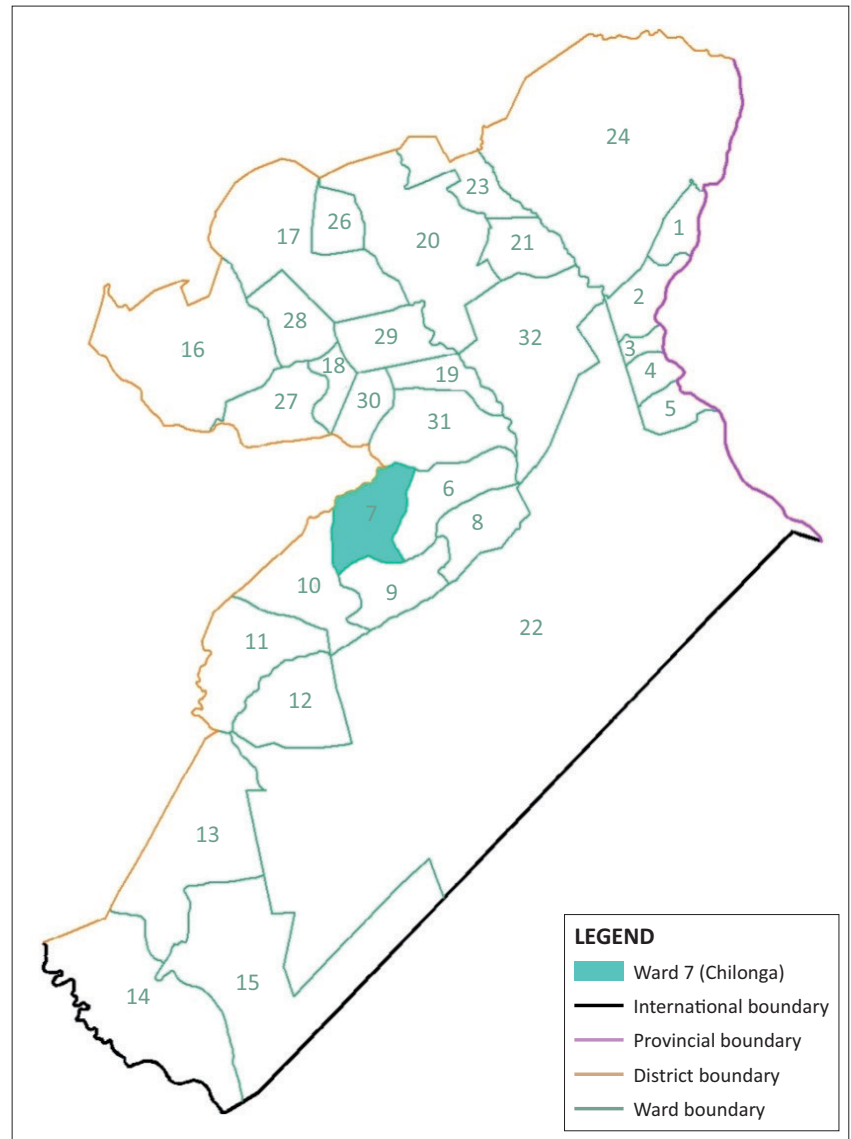

Source: Surveyor General, 2014, Map of Chiredzi produced for: Coping with drought and climate change project, Surveyor General, Harare, Zimbabwe

FIGURE 1: Map of Chiredzi showing location of Chilonga Ward (7).

assessments of economic adaptations show that in some cases returns on financial investments in adaptation are likely to exceed the returns from a baseline situation (Fussel 2007).

Nevertheless, the availability of information alone remains unlikely to motivate adaptation (Cash et al. 2002; Patt \& Schroter 2008). Individuals seek or receive, manage and interpret information in different ways and then use or reject it. Frank et al. (2010) argue that smallholder farmers' knowledge is largely a synthesis derived from personal experience, local sources of knowledge and external sources of techno-scientific information. How farmers perceive scientists and their knowledge is likely to affect farmers' use of scientific information in making decisions. Cash et al. (2002) argue that at the core of any decision process involving the creation of knowledge, individuals assess the salience, credibility and legitimacy of available information. Cash et al. (2003) propose that effective management of these three components of information is central to successful knowledge production and the ability to mobilise knowledge for desired actions.

Individuals are not only motivated by information about risk but also by their direct experience with loss and harm brought about by living with hazards (Kasperson et al. 1988). The process of adaptation is affected by perception of risk and evaluation of information, and also by perception of one's own capacity to adapt or self-efficacy. Motivation theory 
posits that much of human action can be explained through the concept of perceived self-efficacy, defined by Bandura (1977), as concerned with judgments of how well one can execute courses of actions required to deal with prospective situations. Perceived self-efficacy is positively associated with any behaviour from which a desired outcome is anticipated (Bandura 1977). Frank et al. (2010) argue that smallholder farmers are highly perceptive of climate and its impact on their land and crops. When confronting environmental change, however, local knowledge is not always sufficient in building adaptive capacity. To adapt to change, new information is often needed, in this case information about the changing climate and feasible adaptations of farming practices.

\section{Cassava production in Africa}

Cassava (M. esculenta) is the crop with the highest total production in Africa, with 118 million tonnes of productions across the continent in 2010, contributing significant energy input to the population with an average $196 \mathrm{kcal} / \mathrm{capita} /$ day in 2008 (FAO 2010; Smit and Skinner 2002). Cassava is a major staple for more than 500 million people in Africa, and is renowned for its drought tolerance and hardiness in stressful environments (El-Sharkawy 2004). From the few studies which have quantified the impacts or responses of cassava to climate change, Jarvis et al. (2012) found out that cassava is the least affected crop when compared with other major staples such as maize, sorghum and millets. Liu et al. (2008) used the Geographical Information Systems (GIS)-based Environmental Policy Integrated Climate (GEPIC) model to evaluate impacts on cassava production across sub-Saharan Africa, finding a change in production to 2030 of $-2 \%$ to $+1 \%$ depending on the Special Report on Emission Scenarios (SRES). The results were in agreement with those by Lobell et al. (2008) who found cassava to moderately benefit from climate change by 2030 with an average increase of $1.1 \%$ in production from 2000 through the use of statistical models. Jarvis et al. (2012) carried out a research on the impacts of climate change on cassava and compared it with other important African staples such as maize, sorghum, millets, potato, common bean and banana and found that cassava is not affected by soil type and changes in weather patterns. Jarvis et al. (2012) also found that very few studies have focused on cassava when predicting impacts of climate change on crop production, partly because process-based crop models are not accurate or not available at all (Boote et al. 2010; Challinor \& Wheeler 2008; Fermont et al. 2009), and partly because most research on climate change impact assessment has focused on better documented staples such as maize, wheat and rice (Bakker et al. 2008).

Case studies in Nigeria and Ghana revealed that in Ghana cassava is a major crop with a hectarage under cassava was 387000 ha in 1986 and increased to 590000 ha in 1996 (USAID 2005). During the same periods, cassava production also increased from about 2.9 million tonnes to 7.11 million tonnes. Cassava is by far the largest agricultural commodity produced in Ghana and represents 22\% of Agriculture Gross
Domestic Product (AGDP) compared with 5\% for maize and 2\% for rice (Al-Hassan 1989; Day et al. 1996). The 1987/1988 Ghana Living Standards Surveys (GLSS) showed that 1.73 million sampled households $(83 \%)$ were engaged in cassava production compared with 1.74 million $(86 \%)$ in maize production (FAO 2005). In Nigeria, Adeniji et al. (1996) postulated that almost all farmers in the main cassava belts of the south-eastern, south-western and central zones grow cassava. Cassava intercropped as a main or minor crop. Cassava produced in Nigeria is used for human consumption and less than $5 \%$ is used in industries (Adeniji et al. 1996). Cassava as a food crop fits well into the farming systems of the smallholder farmers in Nigeria because it is available all year round, thus providing household food security (Alderman \& Higgens 1992; FAO 2005).

\section{Cassava production in Zimbabwe}

Cassava production in Zimbabwe only takes place on a very limited scale in Mashonaland West and the crop was identified as having potential for increasing diversification in Zimbabwean agriculture (Kleih 1995). Cassava can be used as a food security and industrial crop because it is drought tolerant. There is a need to market cassava as an alternative food to the general populace of Zimbabwe, especially those who live in marginal areas which mainly receive less than $250 \mathrm{~mm}$ of rain and temperatures above $23{ }^{\circ} \mathrm{C}$. In Zimbabwe, cassava production is negligible and has not been the focus of agriculture policy because more emphasis is put on production of cash crops such as maize and tobacco, of which these do not do well in areas like Chiredzi.

\section{Zimbabwe's policy and regulatory framework for dealing with climate change in the agricultural and food security sector}

Zimbabwe under the agriculture and food security cluster is currently developing a climate change policy which emanated from the national climate change response strategy. The policy is meant to increase sustainable intensification and commercialisation of agriculture across agro-ecologies by:

- increasing capacity to generate new forms of practical knowledge, technologies and agricultural support services that meet emerging challenges arising from climate variability and change by supporting research on how indigenous knowledge can be integrated into evidence-based planning premised on good science

- strengthening early warning systems on cropping season quality, rangelands conditions, droughts, floods, disease or pest outbreaks and wildlife movement in order to augment farmer preparedness

- developing frameworks for supporting agricultural specialisation according to agro-ecological zones as well as mechanisms for product exchange, trade and marketing

- increasing the capacity of farmers, extension agencies and private agro-service dealers to take advantage of present and budding indigenous and scientific knowledge on stress-tolerant crop types and varieties 
- developing frameworks for promoting science-based crop production and post-harvest technologies and management practices meant to capacitate, identify and promote the embracing of indigenous and improved livestock breeds that agriculture could sustain (Ministry of Environment, Water and Climate 2015).

\section{Materials and methods}

The research employed a case study design qualitative research methodology which was based on the participants' own categories of meaning and is responsive to local situations, conditions and stakeholders' needs. A total of 120 people who were participants of the GOZ/UNDP/EMA Coping with Drought and Climate Change Project in Chiredzi district, Chilonga Ward as shown on Figure 1 during the period 20072011 were used as research participants. Agriculture adaptation strategies of the primary participants were included in the study. Purposive sampling technique was used to select key informants and focus groups from Agricultural Technical Extension Services (AGRITEX), Chiredzi Rural District Council (CRDC), Environmental Management Agency (EMA) and the Coping with Drought Project Team that implemented the project. A sample of 40 respondents through stratified random sampling had questionnaires administered to them. Twenty households were used for focus group discussions and these were grouped on gender basis. Purposive sampling was used in selecting key informants. Data were grouped into themes for presentation and analysis.

\section{Geographical characteristics of Chiredzi District}

Chiredzi District is in Masvingo Province, Zimbabwe. It is a vast, semi-arid and drought-prone area downstream of the Save and Runde Catchments with altitude generally below $500 \mathrm{~m}$ above mean sea level (Unganai 2011). Chiredzi District borders Mozambique to the east and South Africa to the south - extending over an area of 17629 square kilometres. Chiredzi has a population of 307 436, and an estimate of 276842 people live in the rural areas of the district (ZIMSTATS 2012). Average household size is about five people per household. The key features of district include the Save Conservancy, the Gonarezhou National Park and the Manjinji Pan. There are four major rivers: the Save, Runde, Chiredzi and Mwenezi. Chiredzi lies largely in Natural Region V, a region that experiences less than $400 \mathrm{~mm}$ rainfall per year in most years (Vincent \& Thomas 1960). Natural Region V is an extensive farming region characterised by cattle or game ranching. Lovell (2000) states that temperatures are always very high in summer $\left( \pm 39^{\circ} \mathrm{C}\right)$, causing evaporation losses of $10 \mathrm{~mm}-13 \mathrm{~mm}$ per day. Rainfall in Chiredzi decreases from $700 \mathrm{~mm}$ in the north to less than $500 \mathrm{~mm}$ in the south along the Limpopo Valley (Fewsnet 2007; GoZ-UNDP/GEF 2012).

Annual grasses with scattered shrubs and stunted trees are the main vegetation types (Unganai 2011). Soils are heavy clays. Livestock rearing, of cattle and goats, forms an important component of livelihoods (Wolmer, Sithole \&
Mukamuri 2002). Sorghum, pearl millet, cowpeas and maize are the dominant food crops grown in the region and red sorghum, cotton and groundnuts are the main cash crops (GOZ/UNDP/EMA 2012).

\section{Results and discussion Demographic data}

Table 1 shows that the majority of the respondents were females from the ages 31 to above 51 years old. This has a bearing on their knowledge, experience and enthusiasm in farming.

\section{Marital status of respondents}

Figure 2 shows that $74 \%$ of the respondents are married, $22 \%$ are widowed with the age group above 51 having the highest percentage and $4 \%$ are divorced. The male-headed households are depicted by the respondents who are married. Because of the patriarchal setup in Chilonga, this has a bearing on the decision-making processes, for example, issues of land tenure or types of crops cultivated.

\section{Educational qualifications of respondents}

Figure 3 shows that $45 \%$ respondents in Chilonga Ward attained primary school education, while most of the females above 51 years old had the highest proportion with no formal education, which is $12 \%$. Figure 2 also shows that $32 \%$ of the respondents attained ordinary level. Two percent of the smallholder farmers attained tertiary education. These data show that the literacy levels of all households are very high, and farmers are able to comprehend and to a greater extent appreciate and use information passed on to them by agricultural extension officers.

Table 2 shows that $88 \%$ of respondents have resided in Chilonga for over 25 years; this implies knowledge of the

TABLE 1: Gender and age of respondents.

\begin{tabular}{lccc}
\hline Age group & Male & Female & Total \\
\hline $18-30$ & 3 & 4 & 7 \\
$31-40$ & 3 & 10 & 13 \\
$41-50$ & 6 & 5 & 11 \\
$51+$ & 3 & 6 & 9 \\
\hline Total & $\mathbf{1 5}$ & $\mathbf{2 5}$ & $\mathbf{4 0}$ \\
\hline
\end{tabular}

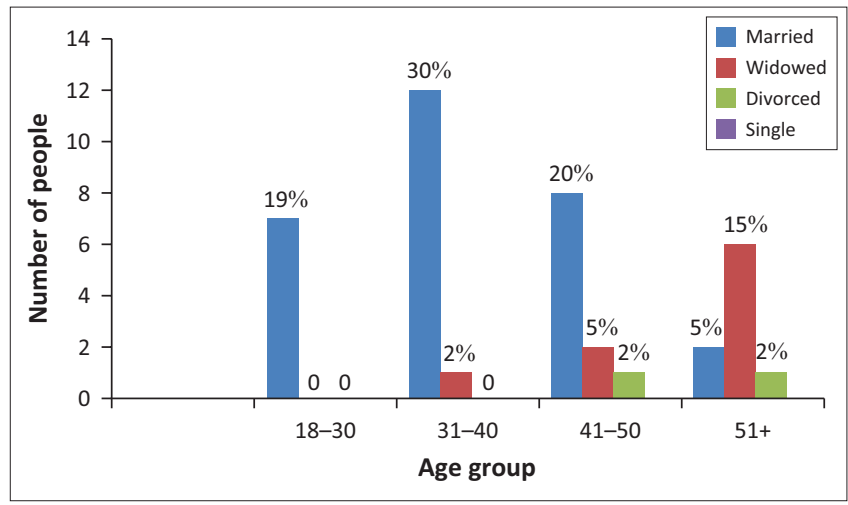

FIGURE 2: Marital statuses of respondents. 
climatic conditions. Of the respondents, 93\% indicated that they were not willing to relocate; they were born in Chilonga and learned to cope with climatic changes. A total of $7 \%$ indicated that they would want to migrate to urban areas or diaspora so as to give back remittances.

The rainfall time series for Chiredzi is shown in Figure 4. The Chiredzi time series for the seasons starting from 1966/1967 to $2010 / 2011$ concurs with the information that was provided by respondents for the period 1980-2014. The season $1999 / 2000$ as depicted in the graph shows that the district received far above normal rainfall.

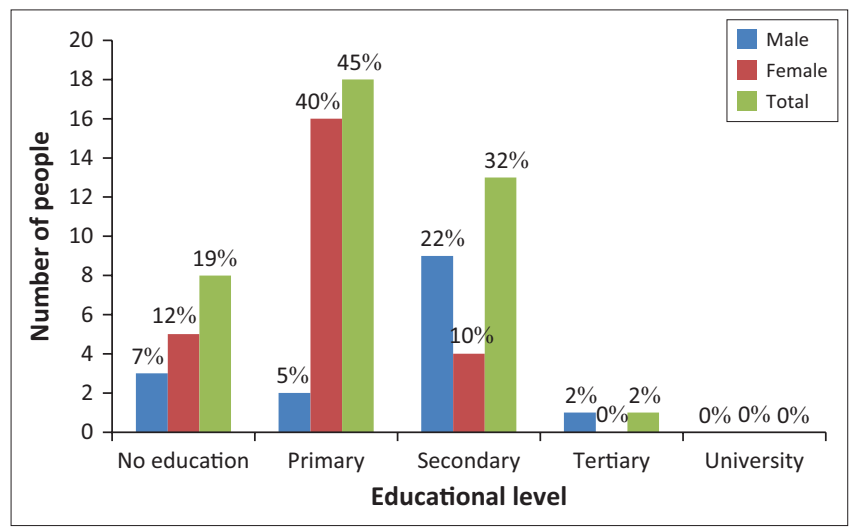

FIGURE 3: Educational qualifications.
Figure 5 shows results of food availability, access, utilisation and sustainability of supply differed among respondents. A total of $88 \%$ respondents indicated that food was available up to the month of August and 12\% indicated food was not available. Sixty percent agreed that food was accessible and $40 \%$ indicated that it was not accessible. Figure 5 also shows that $98 \%$ of the respondents indicated that they were not food secure. This implies that the smallholder farmers in Chilonga were food insecure. In terms of utilisation, all females and $27 \%$ of males indicated that they had knowledge of food utilisation and the other $73 \%$ had no knowledge. Twenty-seven percent of male respondents said they also get the information from the clinic when they accompany their pregnant wives to the clinic. DFID (2000) asserts that food security is about the availability of food, access, utilisation (which is the quality and nutrition) and sustainable supply of the food.

\section{Household socio-economic or livelihood status}

The farmers' responses about their sources of income or livelihood are shown in Figure 6.

Livelihoods are predominantly dependent on rain-fed agriculture and $98 \%$ of the respondents rely on farming and income sources such as remittances from relatives in the urban areas and diaspora, market gardening and

TABLE 2: Period of residence in Chilonga Ward.

\begin{tabular}{|c|c|c|c|c|c|c|}
\hline $\begin{array}{l}\text { Period of residence in } \\
\text { the village }\end{array}$ & $18-30$ & $31-40$ & $41-50$ & $51+$ & Total & Percentage \\
\hline $0-15$ & 1 & - & - & - & 1 & 2 \\
\hline $15-20$ & - & 3 & 1 & - & 4 & 10 \\
\hline Total & 7 & 13 & 11 & 9 & 40 & 100 \\
\hline
\end{tabular}

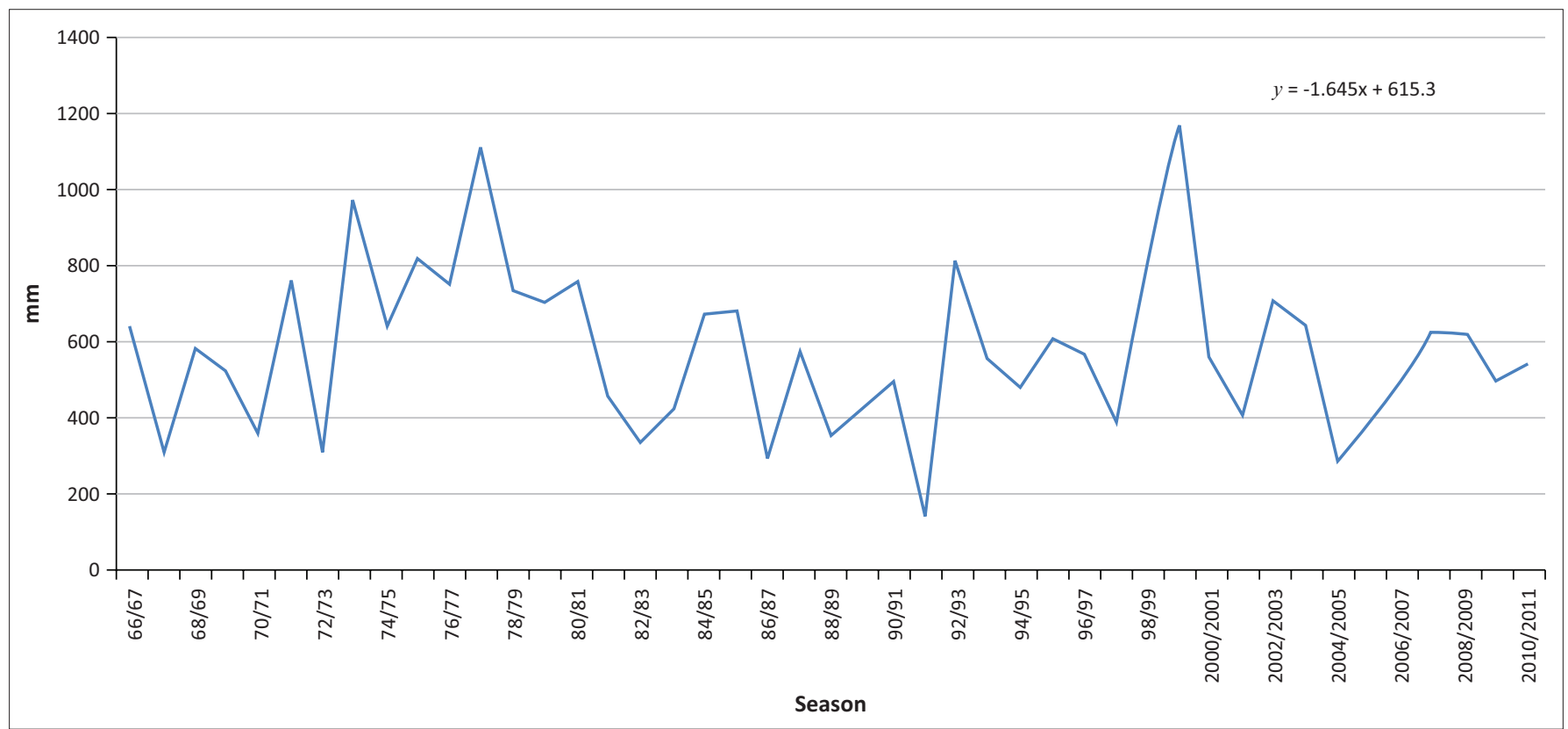

Source: Meteorological Services Department, 2013, Ministry of Environment, Water and Climate, Meteorological Services Department, Harare

FIGURE 4: Chiredzi rainfall time series. 


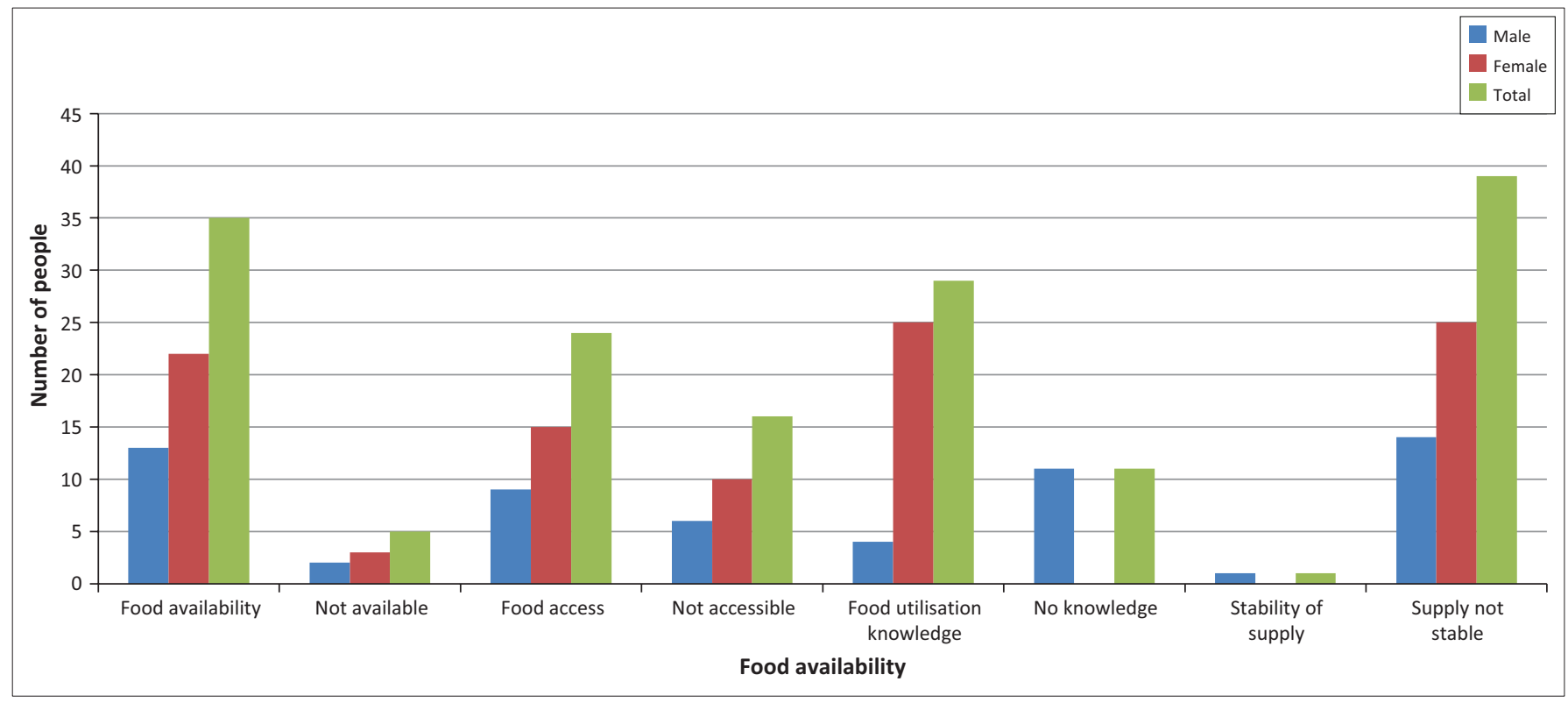

FIGURE 5: Food availability, access, utilisation and stability of supply.

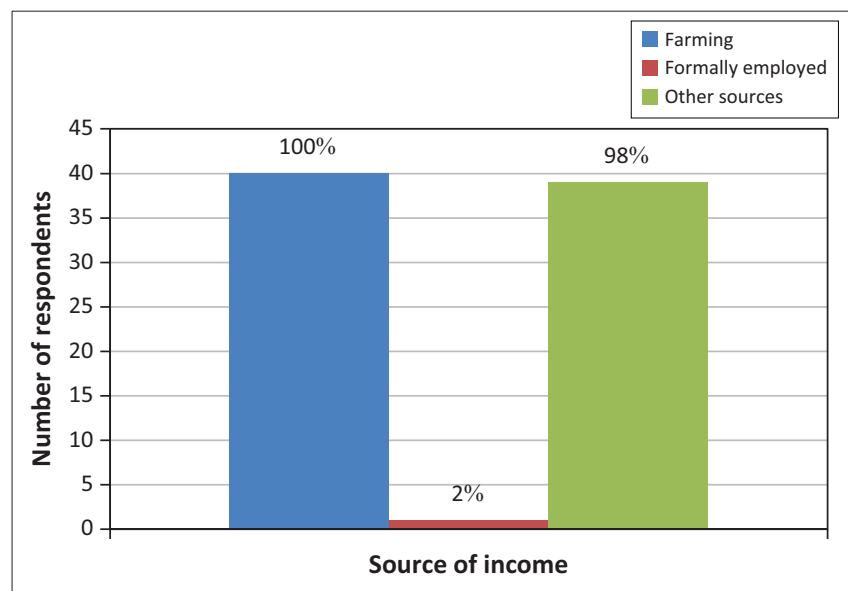

FIGURE 6: Sources of household income.

small-income generating activities as shown in Figure 6. Two percent rely on formal employment and farming. This implies that $98 \%$ of the smallholder farmers are vulnerable to climatic extremes. This was confirmed by the District Agricultural Extension Officer that about 98\% of the farmers experience food shortages during the period September to March when they will have exhausted the previous season's harvest.

\section{Types of crops grown}

Figure 6 shows the types of crops grown in Chilonga Ward.

Figure 7 shows that all respondents (100\%) are into maize and sorghum cultivation. Groundnuts and roundnuts are cultivated by $63 \%$ of the respondents and $53 \%$ of the farmers are into cassava production. In Zimbabwe, agricultural policy encourages production of cash crops such as tobacco and maize at the expense of food crops; therefore, the District Council was promoting and encouraging the production of cassava and small-grain crops, especially pearl millet which is tolerant to heat waves and droughts.

\section{Climate change adaptive strategies employed by the smallholder farmers}

All respondents practice crop diversification, as shown in Figure 8 as well as conservation agriculture practises such as mulching and filtration pits. They are also cultivating drought-tolerant crops such as sorghum, pearl millet, cassava, rapoko and maize varieties that are drought tolerant. Seventy-three percent said that they also practice cultivation of open pollinated varieties, $33 \%$ of the respondents mainly men are practicing cattle fattening with the assistance of Food and Agriculture Organization. Twenty-eight percent of the respondents said that they were practicing water harvesting through digging dead end contours. This implies that farmers in Chilonga are aware of erratic rainfall and high temperatures and therefore engage in the production of crops that are drought tolerant.

\section{Cultivation of cassava}

Figure 9 shows that cultivation of Cassava in Chilonga Ward is still very low, represented by $38 \%$ of females and $15 \%$ male. Twenty-five percent know cassava and are not cultivating the crop and $22 \%$ do not know cassava. Production is still at subsistence level and is for domestic consumption as responded by the $53 \%$ that are practicing cassava production. Seventy-eight percent respondents indicated that women were more interested in cassava production than men. This is an indication that women were more motivated to produce cassava and 38\% were willing to produce cassava crop on large scale. FAO (2005) asserts that in a study that was carried out in Nigeria, it was found out that women play a central role in cassava production, processing and marketing, contributing about 


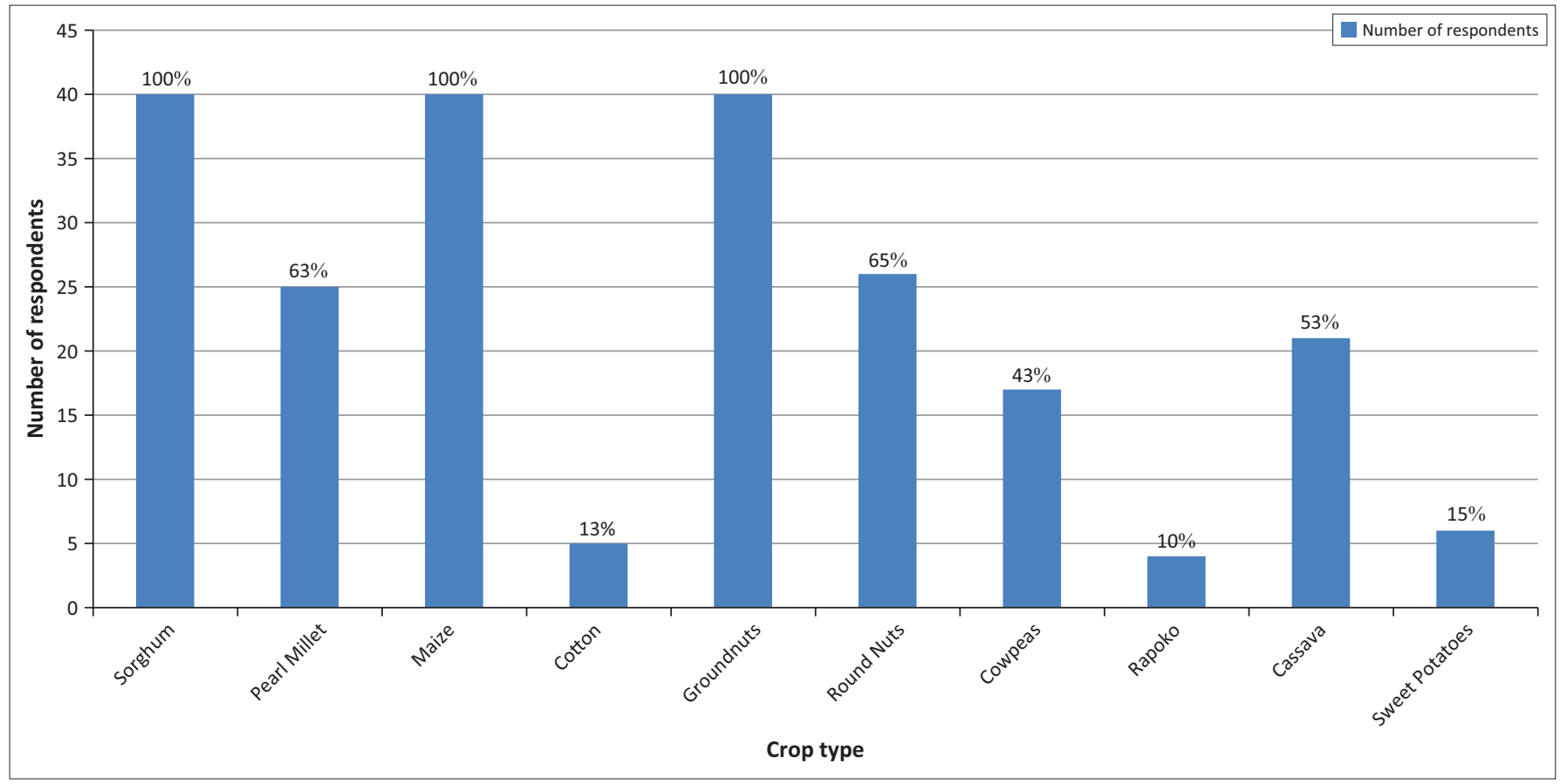

FIGURE 7: Crops that are grown in Chilonga Ward.

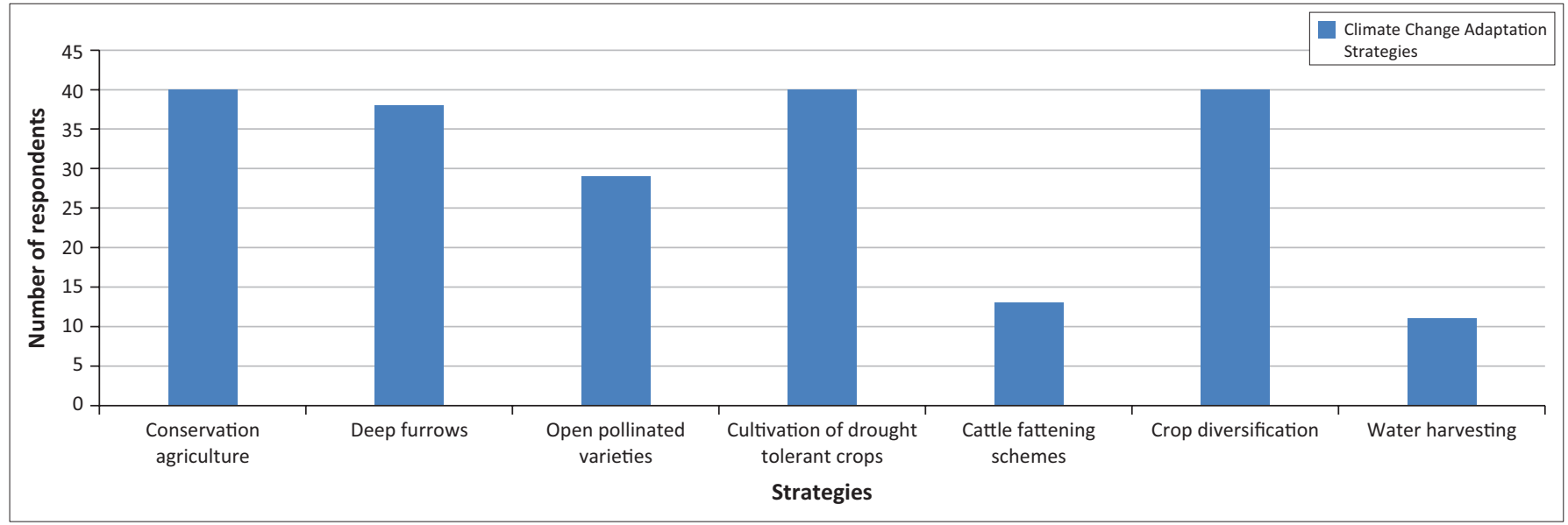

FIGURE 8: Adaptation strategies in Chilonga Ward.

$58 \%$ of the total agricultural labour in the South West, $67 \%$ in the south-east and 58\% in the central zones. FAO (2005) also added that women are said to be entirely responsible for processing cassava which provides them with additional income-earning opportunities and enhances their ability to contribute to household food security. Cassava was introduced as an adaptation option in Chilonga Ward in 2007 by the Ministry of Environment, Water and Climate through EMA and financially supported by United Nations Development Programme (UNDP) through Coping with Drought and Climate Change Programme. By 2010, uptake of cassava remained at less than $1 \%$ and the low uptake was because of limited planting material, limited knowledge of the crop and extension services.

\section{Benefits of cassava}

Fifty-three percent respondents who are into cassava production said that benefits of cassava include consumption of both tubers and leaves. Tubers can be stored in the ground after harvesting for as long as 4 months. Cassava can be prepared and processed for consumption in many different ways, either by just boiling the tuber or by drying and grounding it into powder which can be used to cook sadza (thick porridge) or make bread and which can also be fried as chips (Ceballos 2011; Gleadow et al. 2009). Figure 10 depicts pictures of demonstration of cultivating cassava, drying of grated cassava, pounding of cassava into meal and fried cassava chips. Thirty-eight percent female respondents were much interested in cassava production as a result of these benefits. This implies that more women will be encouraged to produce cassava.

\section{Benefits of cassava production}

Of the respondents, $78 \%$ said that cassava production is not affected by soil type, heat waves, excessive heat or changes in 
weather patterns. They also agreed that the crop requires enough water when planting and afterwards can survive with little water.

\section{Limitations of cassava production}

Limitations of cassava production that came out from $78 \%$ of respondents include little or no knowledge of the crop. Seventy-eight percent of the respondents also indicated that they have limited seed, which is also a limiting factor in large-

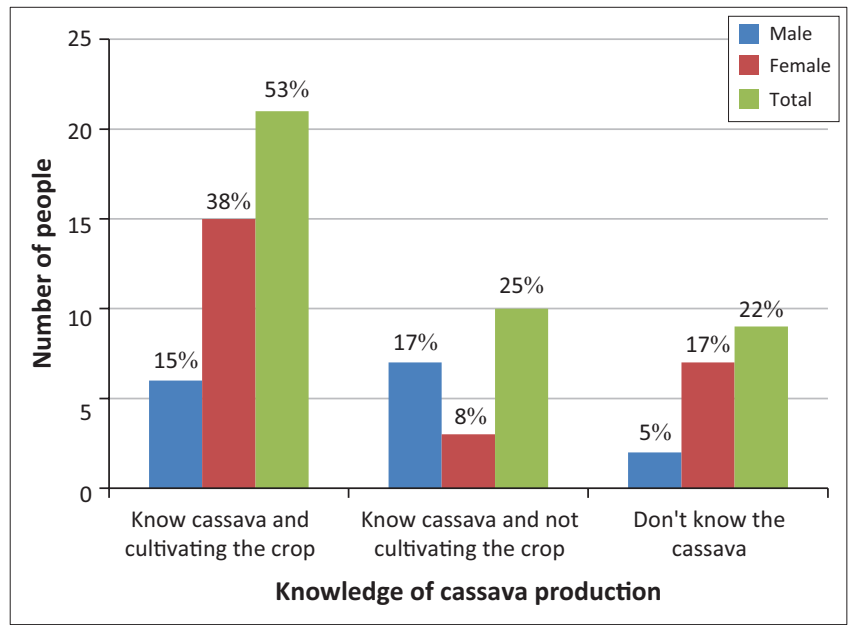

FIGURE 9: Cassava production in Chilonga Ward. scale production. Seed is made available through Chiredzi Research Station at a cost and respondents argued that they lacked financial resources to purchase the seed. However, 38\% indicated that they were going to get the seed cuttings from the cassava crop in Tamuwanyika Garden in Chilonga. Lack of resources was another limitation that was raised by $78 \%$ of the respondents. Fencing material protects the crop from livestock. The respondents echoed that after harvesting of the other crops, cassava will be the only crop that will be green in the fields and, therefore, animals will be attracted to the crop.

\section{Ethical considerations}

Ethical issues were taken into consideration before, during and after data collection process and the subsequent writing process.

\section{Conclusion}

Smallholder farmers remain vulnerable to climate variability and change in Zimbabwe, given their dependence on rainfed agriculture. The farmers are aware of the changing weather patterns, major causes of change, as well as their impacts within their localities and are thus attributing this to climate change. The perception of smallholder farmers that climate is changing is supported by observables such as changes in rainfall amounts, rainfall distribution, onset and cessation of rains and average temperature. Conservation
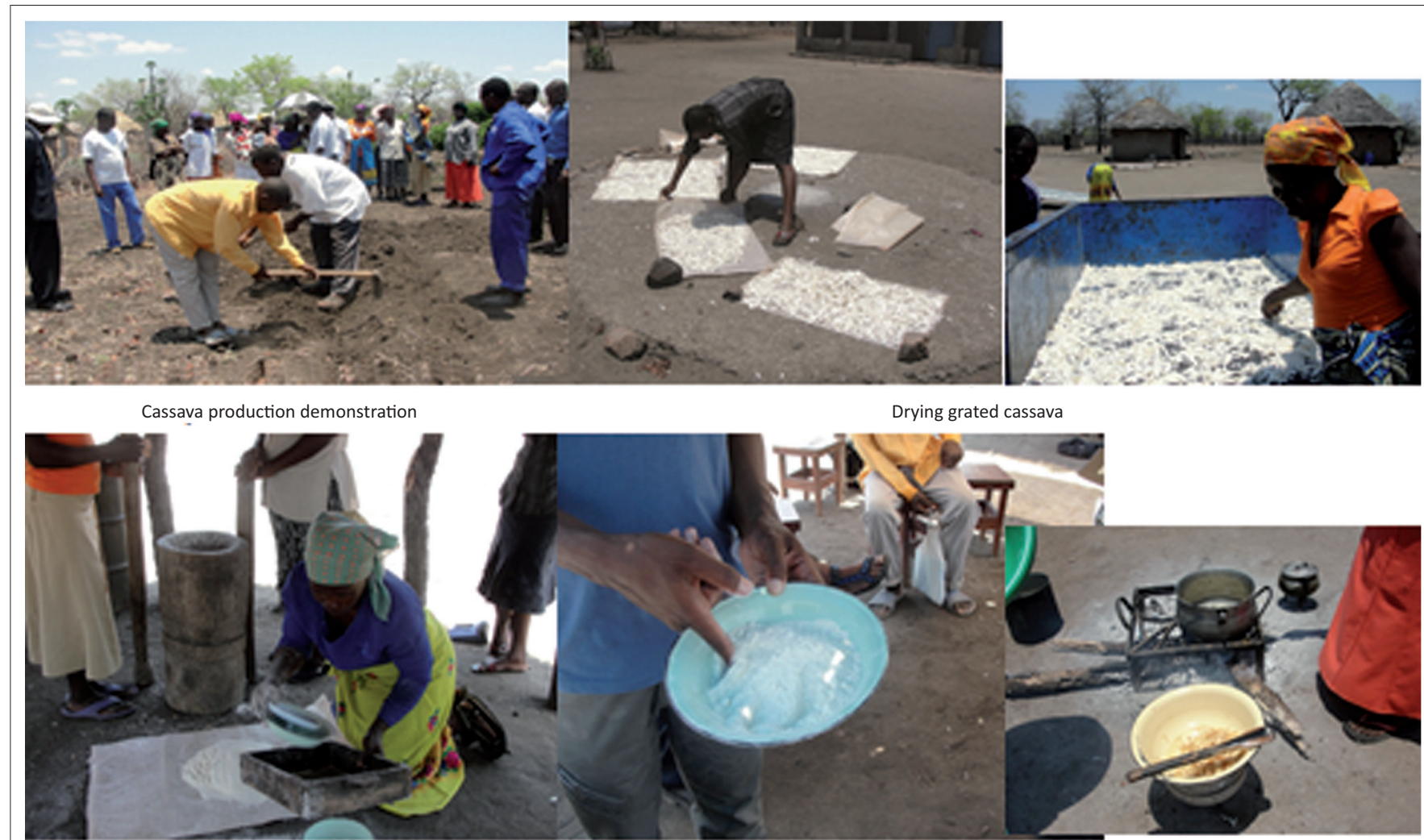

Pounding into a meal

White cassava meal

Fried cassava chips

Source: GoZ-UNDP/GEF, 2009, Coping with drought and climate change project. Climate change: Scenarios for the save catchment of Zimbabwe with special reference to Chiredzi: Synthesis report, Environmental Management Agency, Harare

FIGURE 10: Cultivation and processing of cassava. 
agriculture and production of drought-tolerant crops that thrive in all soil types are some of the major adaptation strategies by smallholder farmers (Herrera Campo, Hyman \& Bellotti 2011). Food security is increased in such areas once drought-tolerant crops such as cassava are grown.

In light of the above conclusions, the study recommends the following:

- There is a need for policy makers to review Zimbabwe's agricultural policy so that it can encourage production of crops such as cassava. Given the increased frequency of extreme weather events induced by climate change, creating a framework for targeted adaptation is crucial to protect people's livelihoods in marginal areas such as the Chiredzi District.

- Farmers willing to grow cassava should be assisted with fencing material and seed; this can be on a loan basis with attractive repayment plan such as payment after sale of harvested produce.

- Farmers, EMA, AGRITEX, Meteorological Services Department (MSD), Livestock Extension Officers and the Rural District Council Officers should invest in climate change adaptation strategies, training and initiation of cassava production.

- The issue of cultivating drought-tolerant crops is not yet a policy, but since independence in 1980 the Government of Zimbabwe has been encouraging farmers to grow cash crops such as tobacco. Instead, the drafting of a climate change policy should be expedited so that the growing of drought-tolerant crops such as cassava could become a major thrust. Adaptation is influenced to a certain extent by governmental actions.

\section{Acknowledgements}

We would like to acknowledge the GoZ/UNDP/GEF (20082012), and the Coping with Drought and Climate Change Project which invoked our thirst to undertake this research.

\section{Competing interests}

The authors declare that they have no financial or personal relationships that may have inappropriately influenced them in writing this article.

\section{Authors' contributions}

T.M. mooted the topic idea when her dissertation was supervised by V.I.T. V.I.T. brought the idea of writing a journal article and did most of the writing, but together with T.M.

\section{References}

Adeniji, A.A., Ega, L.A., Akoroda, M.O., Ugwu, B.O. \& de Balogun, A., 1996, Cassava Development in Nigeria. A Country Case Study towards a Global Strategy for
Cassava Development, Department of Agriculture Federal Ministry of Agriculture Cassava Development, Departm
and Natural Resources, Nigeria.

Alderman, H. \& Higgens, P., 1992, Food and nutrition adequacy in Ghana, Working Paper 27, Cornell Food and Nutrition Policy Programme, Washington, DC.

Al-Hassan, R., 1989, 'Cassava in the economy of Ghana', in F.I. Nweke, J. Lynam \& C.Y. Prudencio (eds.), Status of cassava research in Africa, COSCA working paper no. 3 , pp. 239-273, International Institute of Tropical Agriculture, Ibadan, Nigeria.
Ambrose, M.L. \& Kulik, C.T., 1999, 'Old friends, new faces: Motivation research in the 1990s', Journal of Management 25, 231-292. https://doi.org/10.1177/ 014920639902500302

Asher, C.J., Edwards, D.C. \& Howeler, R.H., 1980, Nutritional disorders of cassava, Department of Agriculture, University of Queensland, St. Lucia.

Bandura, A., 1977, 'Social learning theory', in B.B. Wolman \& L.R. Pomroy (eds.), International encyclopedia of psychiatry, psychology, psychoanalysis, and neurology, vol. 10, pp. 126-129, Van Nostrand Reinhold, New York.

Bakker, A.B., Schaufeli, W.B., Leiter, M.P. \& Taris, T.W., 2008, 'Work engagement: An emerging concept in occupational health psychology', Work \& Stress 22, 187-200. https://doi.org/10.1080/02678370802393649

Booth, J.F., Thompson, L., Patoux, J., Kelly, K.A. \& Dickinson, S., 2010, 'The signature of the midlatitude tropospheric storm tracks in the surface winds', Journal of Climate 23, 1160-1174. https://doi.org/10.1175/2009JCLI3064.1

Brown, D., 2011, 'Making the linkages between climate change adaptation and spatial planning in Malawi', Environmental Science and Policy 14, 940-949. https://doi. org/10.1016/j.envsci.2011.07.009

Burns, C.E., Johnston, K.M. \& Schmitz, O.J., 2003, 'Global climate change and mammalian species diversity in US national parks', Proceedings of the National Academy Sciences USA 100, 11474-11477. https://doi.org/10.1073/pnas.1635115100

Carter, S.E., Fresco, L.O. \& Jones, P.G., 1992, An atlas of cassava In Africa. Historical, agro ecological and demographic aspects of crop distribution, CIAT, Cali, Colombia.

Cash, D.W., Clark, W.C., Alcock, F., Dickson, N.M., Eckley, N., Guston, D. et al., 2003, 'Knowledge systems for sustainable development', Proceedings of the National Academy of Sciences of the United States of America 100, 8086-8091.

Ceballos, H., Ramirez, J., Bellotti, A.C., Jarvis, A. \& Alvarez, E., 2011, 'Adaptation of cassava to changing climates', in S.S. Yadav, R.J. Redden, J.L. Hatfield, H. LotzeCampen \& A.E. Hall (eds.), Crop Adaptation to Climate Change, pp. 411-425, Wiley, New York.

Challinor, A.J. \& Wheeler, T.R., 2008, 'Use of a crop model ensemble to quantify carbon dioxide stimulation of water stressed and well-watered crops', Agricultural and Forest Meteorology 148, 1062-1077. https://doi.org/10.1016/j.agrformet.2008.02.006

Challinor, A.J., Wheeler, T.R., Craufurd, P.Q., Ferro, C.A.T. \& Stephenson, D.B., 2007, 'Adaptation of crops to climate change through genotypic responses to mean and 'extreme temperatures', Agriculture, Ecosystems and Environment 119, 190-204. extreme temperatures', Agriculture, Ecosystem
https://doi.org/10.1016/j.agee.2006.07.009

Chigwada, J., 2009, 'Case study 6: Zimbabwe climate proofing infrastructure and diversifying livelihoods in Zimbabwe', IDS Bulletin 36(4), 103-116. https://doi. org/10.1111/j.1759-5436.2005.tb00237.x

Chitiyo, M. \& Kasele, I., 2004, 'Evaluation of cassava varieties for yield and adaptability in Zimbabwe', African Crop Science Journal 12(3), 197-200.

Day, G., Graffham, A.J., Ababio, J. \& Amoako, M., 1996, Feasibility study: Market potential for cassava-based flours and starch in Ghana, University of Ghana and $\mathrm{NRI}$, Kent, $28 \mathrm{p}$.

DFID, 2000, Achieving Sustainability: Poverty elimination and the environment, DFID, London.

Downing, T., 1991, 'Vulnerability to hunger in Africa: A climate change perspective', Global Environmental Change 1, 365-380. https://doi.org/10.1016/09593780(91)90003-C

Duangpatra, P. 1988, 'Soil and climatic characterizations of major cassava growing areas in Thailand', in R.H. Howeler and K. Kawano (eds.), Cassava breeding and agronomy research in Asia, Proceedings of a Regional Workshop, held in Rayong, Thailand, October 26-28, 1987, pp. 157-184.

El-Sharkawy, M.A., 2004, 'Cassava biology and physiology', Plant Molecular Biology 56, 481-501. https://doi.org/10.1007/s11103-005-2270-7

El-Sharkawy, M.A., 2006, 'International research on cassava photosynthesis, productivity, eco-physiology, and response to environmental stresses in the tropics', Photosynthetica 44(4), 481-512. https://doi.org/10.1007/s11099-006-0063-0

FAO, 2005, Impact of climate change, pests and diseases on food security and poverty reduction, Special event background document for the 31st Session of the Committee on World Food Security, Rome.

FAO, 2007, 'Climate change and food security', in United Nations Joint Press Kit for Bali Climate Change Conference, December 3-14, 2007, Bali , Indonesia.

FAO, 2010, Climate change implications for food security and natural resources management in Africa: Twenty-Sixth Regional Conference for Africa, Food and Agriculture Organization, Luanda.

FAOSTAT, 2010, FAOSTAT: Production, crops, cassava, 2010 data, Food and Agriculture Organization, FAO. Rome.

Fermont, A.M., Van Asten, P.J.A., Tittonell, P.A., Van Wijk, M.T. \& Giller, K.E., 2009, Closing the cassava yield gap: An analysis from smallholder farms in East Africa, Field Crops Research 112, 24-36. https://doi.org/10.1016/j.fcr.2009.01.009

FEWSNET, 2007, Zimbabwe food security outlook October 2007 to March 2008, FEWSNET, Harare.

Frank, D.C., Esper, J., Raible, C.C., Büntgen, U., Trouet, V., Stocker, B. et al., 2010, 'Ensemble reconstruction constraints on the global carbon cycle sensitivity to climate', Nature 463(7280), 527-530. https://doi.org/10.1038/nature08769

Füssel, H.M., 2007, 'Vulnerability: A generally applicable conceptual framework for climate change research', Global Environmental Change 17, 155-167. https://doi. org/10.1016/j.gloenvcha.2006.05.002

Gleadow, R.M., Evans, J.R., McCaffery, S. \& Cavagnaro, T.R., 2009, Growth and nutritive value of cassava (Manihot esculenta Cranz.) are reduced when grown in elevated carbon dioxide, School of Biological Science, Monash University, Victoria. 
GoZ-UNDP/GEF, 2009, Coping with drought and climate change project. Climate change: Scenarios for the save catchment of Zimbabwe with special reference to Chiredzi: Synthesis report, Environmental Management Agency, Harare.

GoZ/UNDP/GEF, 2012, Coping with drought and climate change project: A summary report of project achievements (2008-2012), Environmental Management Agency, Harare.

Hahn, S.K., Reynolds, L. \& Egbunike, G.N. (eds.), 1988, Cassava as livestock feed in Africa: Proceedings of the IITA/ILCA/University of Ibadan workshop on the potential utilization of cassava as livestock feed in Africa, International Institute of Tropical Agriculture (IITA) and Addis Ababa, Ethiopia: ILCA, 14-18 November, 1988, Ibadan, Nigeria.

Herrera Campo, B., Hyman, G. \& Bellotti, A., 2011, 'Threats to cassava production: Known and potential geographic distribution of four key biotic constraints', Food Security 3(3), 329-345. https://doi.org/10.1007/s12571-011-0141-4

IPCC, 2007, Climate Change 2007: Impacts, Adaptation and Vulnerability. Working Group II Contribution to the Fourth Assessment Report of the Intergovernmental Panel on Climate Change, Cambridge University Press, Cambridge, UK.

IPCC, 2010, 'Guidance note for lead authors of the IPCC fifth assessment report on consistent treatment of uncertainties', in IPCC Cross-Working Group Meeting on Consistent Treatment of Uncertainties, Jasper Ridge, CA.

Jarvis, A., Ramirez-Villegas, J., Herrera Campo, B.V. \& Navarro-Racines, C., 2012, 'Is cassava the answer to African climate change adaptation', Tropical Plant Biology 5(1), 9-29. https://doi.org/10.1007/s12042-012-9096-7

Kamukondiwa, W., 1996, 'Alternative food crops to adapt to potential climatic change in Southern Africa', Climate Research 6, 153-155. https://doi.org/10.3354/ cr006153

Kasperson, R.E., Renn, O., Slovic, P., Brown, H.S., Emel, J., Goble, R. et al., 1988, 'The social amplification of risk a conceptual framework', Risk Analysis 8, 177-187. https://doi.org/10.1111/j.1539-6924.1988.tb01168.x

Kleih, U., 1995, 'Potential of cassava in Zimbabwe: A case study for the southern Africa region' [Potentialités du manioc au Zimbabwe: Une étude de cas pour les région du sud de l'Afrique], in T. Agbor Egbe, B. Alain, D. Griffon \& T. Serge (eds.) Transformation alimentaire du manioc Cassava food processing, pp. 75-87, ORSTOM, Paris (Colloques et Séminaires).

Liu, J., Fritz, S., Van Wesenbeeck, C.F.A., Fuchs, M. \& You, L., 2008, 'A spatially explicit assessment of current and future hotspots of hunger in Sub-Saharan Africa in the context of global change', Global and Planetary Change 64, 222-235. https://doi. org/10.1016/j.gloplacha.2008.09.007

Lobell, D.B., Bonfils, C. \& Duffy, P.B., 2007, 'Climate change uncertainty for daily minimum and maximum temperatures: A model inter-comparison', Geophysical research letters 34(5), n.p.
Lovell, C.J., 2000, Productive water points in dryland areas, quidelines on integrated planning for rural water supply, ITDG Publishing, London.

Meteorological Services Department, 2013, Ministry of Environment, Water and Climate, Meteorological Services Department, Harare.

Ministry of Environment, Water and Climate, 2015, Zimbabwe's policy and regulatory framework for dealing with climate change in the agricultural and food security sector, Ministry of Environment, Water and Climate, Harare, Zimbabwe.

Mitchell, T.R., 1982, 'Motivation: New directions for theory, research, and practice', The Academy of Management Review 7, 80-88.

Patt, A.G. \& Schroter, D., 2008, 'Perceptions of climate risk in Mozambique: Implications for the success of adaptation strategies', Global Environmental Change 18, 458-467. https://doi.org/10.1016/j.gloenvcha.2008.04.002

Sieber, S., Konig, H., Bezlepkina, I. \& Reidsma, P., 2010, Different levels of stakeholder participation for sustainability impact assessment tools - A comparative analysis of four research approaches, Leibniz Centre for Agricultural Landscape Research, Germany.

Smit, B. \& Skinner, M., 2002, 'Adaptation options in agriculture to climate change: A typology', Mitigation and Adaptation Strategies for Global Change 7, 85-114. https://doi.org/10.1023/A:1015862228270

Surveyor General, 2014, Map of Chiredzi produced for: Coping with drought and climate change project, Surveyor General, Harare, Zimbabwe.

Unganai, L., 2011, Impacts of climate change on agriculture: A case study documentation, GoZ/UNDP/GEF, Harare.

USAID, 2005, Cassava Enterprise Development Project, International Institute of Tropical Agriculture, IITA, Ibadan, Nigeria.

Vincent, V. \& Thomas, R.G., 1960, An agro-ecological survey of Southern Rhodesia Part1 in agro-ecological survey, Government Printers, Salisbury, pp. 1-217.

Wolmer, W., Sithole, B. \& Mukamuri, B., 2002, 'Crops, livestock and livelihoods in Zimbabwe', in I. Scoones \& W. Wolmer (eds.), Pathways of change in Africa: Crops, livestock and livelihoods in Mali, Ethiopia and Zimbabwe, pp. 122-161, James Currey, Oxford.

Zhang, L., Luo, R., Hongmei, Y. \& Tyler, S., 2008, Climate Adaptation in Asia Knowledge Gaps and Research Issues in China Final Report to IDRC and DFID (40pp), Centre for Chinese Agricultural Policy (CCAP), Chinese Academy of Sciences (CAS), Institute for Social and Environmental Transition (ISET), and Institute of Geographic Sciences and Natural Resources Research (IGSNRR) Beijing, China.

ZIMSTATS, 2012, Zimbabwe population census, Zimbabwe National Statistics Agency, Harare, Zimbabwe. 